DIsTRICTS COLONIZABLE BY Smynthurus viridis L., (1) FAVOURABLE, (2) HIGHYY FAVOURABLE.

\begin{tabular}{|c|c|c|}
\hline New Zealand & Many stations & $\begin{array}{l}\text { Auckland, New Plymouth, } \\
\text { Wellington, Dunedin, In- } \\
\text { vercargill, Rotorua, Nel- }\end{array}$ \\
\hline W. Australia & $\begin{array}{l}\text { Guildford, Perth, } \\
\text { Northam, Narrogin }\end{array}$ & $\begin{array}{l}\text { Watheroo, Albany, Bridge- } \\
\text { town, Bunbury, Cape } \\
\text { Leeuwin, Cape Natural- } \\
\text { iste, Collie, Esperance, } \\
\text { Karridale, York }\end{array}$ \\
\hline 8. Australia & Adelaide, Cape & Port Lincoln, Cape Borda, \\
\hline Victoria & $\begin{array}{l}\text { Cowes, Colac, Hamil- } \\
\text { ton, Portland, Ter- }\end{array}$ & $\begin{array}{l}\text { Gabo Island, Wilson's Pro- } \\
\text { montory, Lorne, Cape Ot- }\end{array}$ \\
\hline N.S. Wales & $\begin{array}{l}\text { Lismore, Maitland } \\
\text { West, Bowral, Par- } \\
\text { ramatta, Adelong }\end{array}$ & $\begin{array}{l}\text { Kempsey West, Port Mac- } \\
\text { quarie, Sydney, Jervis Bay } \\
\text { Nowra, Moruya Heads }\end{array}$ \\
\hline Tasmania & $\begin{array}{l}\text { Stanley, Eddystone } \\
\text { Point, Zeehan, } \\
\text { Launceston }\end{array}$ & $\begin{array}{l}\text { Hythe, Cape Sorell, War- } \\
\text { atah, Currie }\end{array}$ \\
\hline
\end{tabular}

(1)

(2)

countries to which Smynthurus is potentially a serious economic menace, the most important being Now Zealand, the south-west comer of Cape Province, Natal, Chile, New South Wales, and the United States of America". At the same time, an attempt was made to portray, in greater detail, the limits of existence and of economic significance of the insect in Australia, on account of its known depredations in Western and South Australia. This led to the conclusion (loc. cit., p. 183), "that there is a large tract of country in New South Wales and southern Victoria from which the insect has not yet been recorded, but to which, in the event of its introduction, it would undoubtedly prove to be a serious economic problem. Also, there exists a fairly large band of territory in the north and western parts of Tasmania which is highly favourable... although the insect ... has not yet had time to demonstrate its full potentialities as regards numerical increase". In view of recent reports upon the economic status of Smynthurus, these statements are of considerable interest to biologists in general and to ecologists in particular.

Thus, commenting on the lucerne flea in Tasmania,

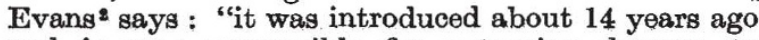
and is now responsible for extensive damage to pastures"; whilst Pescott ${ }^{3}$, discussing the colonization of Victoria by the species, remarks that this "introduced insect, was, until several years ago, confined to the coastal areas of the Western District of Victoria, but recently it has been found scattered over other portions of the State". Entomologists of the Australian Council for Scientific and Industrial Research" report that the pest now occurs "in isolated areas in other districts in this State [Victoria] and in southern New South Wales". The situation in New Zealand has been summarized recently by Dumbleton", thus, "In the North Island, the lucerne flea is known to be widely distributed in an area including Bulls, Palmerston North, Dannevirke, Woodville and Eketahuna. There is one isolated occurrence of the flea near Pokeno and another near Maraekakaho. In the South Island, the insect was found to be present over an area including Temuka, Timaru, Waimate, Oamaru, Mosgiel, Balclutha and Gore.".

Hence, the predictions ventured by me in 1932 have materialized sooner than I expected. The accompanying map indicstes, by means of dotted lines (Australia), and by triangles (New Zealand), the known distribution of the insect in numbers of economic significance; while the climatically favourable and highly favourable areas (based on the original climatic criteria) are represented by means of a dot and a dotted circle, respectively. It is my belief that prediction of the abundance and distribution of animal-populations is a field of scientific endenvour which will yield results of great interest and value. With the co-operation of biologists and meteorologists this branch of ecology should be one of the most powerful weapons in the armoury of the economic biologist.

1 Maclagan, D. S., Bull. Entom. Res., 23, 151 (1932).

Evans, J. W., Tasman. J. Agric., 8, 93 (1937).

${ }^{3}$ Pescott, R. T., J. Dept. Agric. Vict., 35, 371 (1937).

- Rep. Coun. Sci. Indus. Res. Australia, 11 (1937).

- Dumbleton, L. J., N.Z. J. Sci. and Tech., 20, 197A (1938).

\section{CONDITIONS IN FACTORIES}

TN a paper "Factory Inspection: a thirty-five [years" Retrospect", given before the Royal Statistical. Society on May 20, which has now appeared in the Journal of the Royal Statistical Society, Sir Duncan Wilson gives a most interesting picture of the developments under the Factory Acts leading to the prevention of accidents and the elimination of industrial disease, as well as indicating points at which statistical information is still lacking or incomplete. Between 1904 and 1938 the staff of the inspectorate more than doubled. Sir Duncan Wilson paid a warm tribute, which was endorsed in the subsequent discussion, to the way in which from the start the factory inspectors, relying on education and persuasion rather than on the full exercise of their statutory powers, had secured the co-operation of employers and managements. In the same period the expenditure had more than trebled and the figures quoted by Sir Duncan Wilson emphasized the huge increase in the use of mechanical power. While the number of factories has increased by about 70 per cent, the number of workshops or places without mechanical power has been reduced to about one half. The data show that industrial diseases have been fought with much greater success than accidents. Fatal accidents per 100,000 employed decreased from 17.6 in 1904 to 11.2 in 1938 and this decrease may be taken as a measure of the severe accident rate. On the other hand, reported accidents almost doubled in the same period. As the criteria were more stringent in 1904 the difference is much greater than would appear from the actual figures.

Sir Duncan Wilson notes that, although of late the proportion of very large factories has increased, about one third of the working population is accom. modated in factories employing not more than a hundred workers and more than one half in factories employing not more than two hundred and fifty workers. The chief work of the factory inspector in fact lies in quite small factory units and the trouble there, as Mr. A. W. Garrett pointed out in the discussion, is that there is often not the broad outlook which characterizes the management in the larger concerns. Sir Duncan also directed attention to the high incidence of accidents among young workers under eighteen.

Statistical treatment of the available data over the period explored indicates a distinct tendency for the numbers employed to rise associated with a smaller tendency for accidents generally to rise and with a tendency for fatal and presumably other severe accidents to fall. The two curves are roughly 
parallel, variations in numbers employed being positively associated with similar variations not only in the mere numbers of accidents but also with the risk of incurring them. Of the more personal aspects of industry, Sir Duncan does not think that the loss of paternalism involved in modern times in the formation of large combines replacing or absorbing the small employers is a pure loss, but emphasizes that many and probably most of the small employers were first concerned with profit and lastly with the safety, health and general interests of their workers. $\mathrm{He}$ refers to the noticeable change in the workers themselves and asserts that the bedraggled, illmannered and ill-spoken worker has been replaced by one with self-respect, good appearance and the best manners of any social class. Sir John Forbes Watson, in the discussion which followed, referred to the importance of the analysis of factory conditions in Great Britain as compared with others and the importance of developments in industrial medicine was stressed by Dr. H. B. Morgan, who paid a particularly warm tribute to the work of the factory medical inspectors. Mr. Robert R. Hyde, director of the Industrial Welfare Society, in a written communication, referred to the importance of ways and means of providing the smaller units of industry with some form of the medical service which has already been developed with such success in many large firms.

\section{RECONSTRUCTION AND ECONOMICS}

TN a pamphlet entitled "Post-War Poverty and Unemployment Can be Prevented" issued last year (see NATuRE, 146, 312; 1940) T. W. Wyatt and D. Caradog Jones challenged the assumption that a period of intense economic depression and serious unemployment is bound to follow the War, and urged that, on the contrary, it should be possible by a carefully thought-out plan, co-ordinating all forms of industrial activity, to change over from war production to peace production, utilizing the vastly improved capacity of production for creating new wealth. A postscript by J. R. Bellerby outlined five stages by which this could be achieved. Messrs. Wyatt and Caradog Jones have now, under the title "Britain's New Order"*, issued as a sequel a further thoughtful study of methods of preventing post-war unemployment, which deals with some of the questions and doubts raised by their earlier pamphlet.

The pamphlet urges that local authorities should be encouraged to prepare schemes of work to put into operation as soon as ever private demand slows down after the burst of activity which may be anticipated immediately after the War. Government departments which are able to do so should set an example by initiating public works when the suitable moment arrives. The appointment of a commission with members drawn from all walks of life and responsible to Parliament is suggested to decide which schemes of public work should have preference and to regulate the purchase of surplus foods and materials for storage in different parts of the country. The criterion for determining the approval of or vetoing of any particular scheme should be its consistency with, or opposition to, the public interest.

*Britain's "New Order" : a Plea for a Sane Post-War Employment Policy. By T. W. Wyatt. and D. Caradog Jones. Pp. 32. (Birkenhead: John WooIman and Sons, 1941.) 9d.
Every effort should be made to decentralize as much as possible and to interfere as little as possible with private initiative, subject only to the over-riding conditions that the national and municipal interest must come first.

Messrs. Wyatt and Jones urge that modern powers of production are so vast that they must be regulated or they will overwhelm us. It is within our power at the end of the War to build a new world, but we must scrap our old impressions of scarcity and of the need for all-round sacrifice to pay for the War. Taxes, accordingly, they consider should be made as light as possible, and they should be raised or lowered solely for the purpose of regulating purchasing power.

Money or credit required to keep production and exchange functioning should be created directly by the Government up to a strict limit when labour, machinery and materials were all fully and efficiently employed. This demands a high degree of skilled organization for which training and time may be required, and although Messrs. Wyatt and Jones believe that no radical change in the present economic system is required, they point out that sudden transition from a system based on production for profit to a new system based on production for use would be dangerous. The present system can be made to provide a much higher standard of life than we have hitherto enjoyed, and this higher standard will permit us to acquire the better education which is the pre-requisite for the organization of a more rational and efficient system of production for use and service.

All the machinery for a great forward stride, given the right direction and control, is at our command. The large surpluses of all kinds of commodities which are piling up in various parts of the world are as important to the countries of their origin as to those that receive them. Much of the urgent reconstruction required over a wide area will be completed in a relatively short time, and all this work must be undertaken regardless of cost. Purchasing power is the key to distribution, and the solution of the problem of distribution will remove one of the most potent obstacles in the path of a settled peace.

In their attempt to build on past experience, the authors are undoubtedly in keeping with the British tradition, and the work which it is proposed should be entrusted to a Parliamentary Commission is already largely in the hands of the Cabinet Committee under Mr. Arthur Greenwood, the Ministry of Works and Building, or the Leith-Ross Bureau.

Essentially the same ideas are outlined in two artıcles which have appeared in the October number of the American periodical Fortune. In the first of these, Mr. Geoffrey Crowther, editor of the Economist, at present visiting the United States, enters a powerful plea for a political democracy which includes a balance, and not merely a mixture, of the social and the profit motives. Mr. Crowther suggests, for example, that the whole of the question of food supply should be removed, in peace as in war, from the operation of the profit motive, and the incentive of order, or purposeful organization by the community, substituted for that of freedom and private profit, in much the same way that education is already organized on a service basis. The concept of social security, however, should not be limited to the satisfaction of basic needs. The extended Bill of Rights must be accompanied by an extended Bill of Duties including specific social service, whether in the defence forces, the health services, or in what- 